\title{
Association between land use, land cover, plant genera, and pollinator abundance in
}

\section{mixed-use landscapes}

Vishesh L. Diengdoh ${ }^{1}$, e: vishesh.diengdoh@utas.edu.au, ORCID: https://orcid.org/0000$\underline{0002-0797-9261}$

Barry W. Brook ${ }^{1,2}$ - e: barry.brook@utas.edu.au

Mark Hunt ${ }^{1,3}$ - e: M.Hunt@utas.edu.au

Stefania Ondei ${ }^{1}$ - e: stefania.ondei@utas.edu.au

${ }^{1}$ School of Natural Sciences, University of Tasmania, Private Bag 55, Hobart TAS 7005

Australia

${ }^{2}$ ARC Centre of Excellence for Australian Biodiversity and Heritage, Australia

${ }^{3}$ ARC Industrial Transformation Training Centre for Forest Value, Australia

Corresponding Author: Vishesh L. Diengdoh

\section{Acknowledgements}

This work was supported by the Australian Research Council [grant number FL160100101].

The authors acknowledge the Pydairrerme people, traditional custodians of the land where fieldwork was carried out. We thank the different landowners for the permission provided to carry out fieldwork on their properties. We would also like to thank the volunteers who assisted with fieldwork. 


\section{Declarations}

\section{Funding}

This work was supported by the Australian Research Council [grant number FL160100101].

\section{Conflicts of interest}

None.

\section{Availability of data and material}

Included as Online Resources.

Code availability

Not included.

Authors' contributions

VLD proposed and designed the study, carried out the fieldwork, analysed the data and wrote the manuscript. BWB, MH and SO all contributed significantly to the study design, result interpretation, and the structuring and editing of drafts of the manuscript.

\section{Ethics approval}

Fieldwork was carried out following the ethics outlined by the Animal Ethics Committee, University of Tasmania under Project No: A0016856 and Department of Primary Industries, 
bioRxiv preprint doi: https://doi.org/10.1101/2021.01.20.427393; this version posted July 22, 2021. The copyright holder for this preprint (which

was not certified by peer review) is the author/funder, who has granted bioRxiv a license to display the preprint in perpetuity. It is made available under aCC-BY-NC-ND 4.0 International license.

Parks, Water and Environment (DPIPWE) Tasmania, for fieldwork permits in protected areas, under Authority No's. FA17315 and FA18185.

Consent to participate

Not applicable.

Consent for publication

All the authors have reviewed the manuscript and provided consent for publication. 


\section{Abstract}

2 Pollinators are globally threatened by land-use change, but its effect varies depending on the

3 taxa and the intensity of habitat degradation. However, pollinator-landscape studies typically

4 focus on regions of intensive human activities and on a few focal species. Evaluating

5 pollinator responses in landscapes with moderate land-use changes and on multiple pollinator

6 groups would therefore fill an important knowledge gap. This study aims to determine the

7 predictive capacity and effect of habitat characteristics on the relative abundance of multiple

8 pollinator groups in mixed-use landscapes. To do this, we collected field data on the relative

9 abundance of nectivorous birds, bees, beetles, and butterflies across the Tasman Peninsula

10 (Tasmania, Australia). We then applied Random Forests to resolve the effects of land use

11 (protected areas, plantation, and pasture), land cover at different radii (100 $\mathrm{m}$ and $2000 \mathrm{~m}$ ),

12 and plant genera on pollinator abundance. Overall, land cover and plant genera were more

13 important predictors of pollinator abundance than land use. And the effect of land use, land

14 cover, and plant genera varied depending on the pollinating group. Pollinator groups were

15 associated with a range of plant genera, with the native genera Acacia, Leptospermum,

16 Leucopogon, Melaleuca, Pomaderris, and Pultenaea being among the most important

17 predictors. Our results highlight that one size does not fit all-that is pollinator response to

18 different landscape characteristics vary, emphasise the importance of considering multiple

19 habitat factors to manage and support a dynamic pollinator community, and demonstrates

20 how land management can be informed using predictive modelling.

\section{Keywords}

22 Bees, beetles, butterflies, honeyeaters, Random Forests, land-use 


\section{Introduction}

24 Pollinators are declining globally (Maes and Van Dyck 2001; Ollerton et al. 2014; Regan et

25 al. 2015) due to the interactions and synergies between land-use change (habitat loss and

26 fragmentation), introduced and invasive species, agrochemicals, and climate change (Potts et

27 al. 2010; Regan et al. 2015; Vanbergen and Insect Pollinators Initiative 2013). Of these, land-

28 use change is widely considered the most important threat to pollinators as it affects plant

29 abundance and diversity, in turn reducing the availability of floral resources (Baude et al.

30 2016; Nicolson and Wright 2017; Paton 2000). This could have major cascading

31 consequences for many habitats, as pollinators (animal vectors of pollen) are important

32 ecosystem components and are estimated to globally pollinate $70 \%$ of crops (Klein et al.

33 2007) and $87 \%$ of wild plants (Ollerton et al. 2011).

34 While land-use change has an overall negative effect on pollinator abundance and richness

35 (Winfree et al. 2011), this effect varies between different pollinating taxa, extent of landscape 36 changes, and ecosystems (Millard et al. 2021; Montero-Castaño and Vilà 2012; Winfree et al.

37 2009). Yet, the literature on impact of landscape changes on pollinators is mostly focused on

38 Hymenoptera (Senapathi et al. 2016) and in landscapes with extreme changes (Winfree et al.

39 2011). This raises the question of how bees and non-bee pollinating taxa would be impacted

40 by landscapes subject to moderate alteration. Identifying the differences in the impacts of

41 land-use types on different taxa would allow us to design better management policies.

42 Irrespective of the type of land use, plant species richness can have a positive impact on

43 insect pollinators (Kral-O'Brien et al. 2021). For example, agricultural landscapes that

44 include high-quality habitats support a higher abundance and richness of pollinators than

45 agricultural landscapes without such habitats (Kavanagh et al. 2007; Kennedy et al. 2013). In 
46 this context, targeted plantings can be used to attract and sustain pollinators in degraded

47 ecosystems (Menz et al. 2011). Pollinator restoration can be accomplished by using a subset

48 of all available plant families or species (Campbell et al. 2019; Sabatino et al. 2021). That

49 raises the question of whether there are plants (or plant groups) that are relatively more

50 effective in sustaining pollinators and, if so, which species/characteristics are best suited for

51 which taxa. Identifying and managing such plants would be beneficial in sustaining pollinator

52 communities.

53 In this study, we aim to assess the predictive capacity and effect of land use, land cover, and

54 plant genera on the relative abundance (count) of nectivorous birds, bees, beetles, and

55 butterflies. To do this, we collected field data across protected areas, plantations, and pastures

56 using the Tasman Peninsula (Tasmania, southern-temperate Australia) as a case study of a

57 diverse, mixed-use landscape. We used Random Forests (Liaw and Wiener 2002) for

58 predictive modelling, as it is a non-parametric decision-tree-based method commonly used in

59 predictive analysis of complex, conditional data (Greenwell 2017). The advantage of using

60 machine learning and predictive modelling is its ability to handle data with non-normal

61 distribution and noise, deal implicitly with interactions, and use robust training-and-testing

62 analysis to make predictions for informed decision making (Thessen 2016; Willcock et al.

63 2018). We discuss the associations between predictors and pollinators and which predictors

64 should be managed to improve the diversity and resilience of pollinator communities. 


\section{Methods}

\section{Study area}

68 The Tasman Peninsula, located in the south-eastern portion of the large island of Tasmania,

69 Australia (Fig. 1), covers an area of $660.4 \mathrm{~km}^{2}$ with elevation from 0 to $582 \mathrm{~m}$ a.s.l. (meters

70 above sea level). It is characterised by a mix of dry and wet sclerophyll eucalypt forest and

71 dry coastal vegetation, and supports a third of the vascular plants found in Tasmania with 556

72 vascular plants, of which there are 336 dicotyledons (Brown and Duncan 1986). It was

73 selected as a study area as its landscape experienced only moderate anthropogenic change

74 relative to surrounding regions, since over a quarter $(26.7 \%)$ of its area is protected

75 (Australian Bureau of Statistics 2021). Overall, the study area is dominated by grazing

76 pasture, forest plantations and protected areas (Department of Primary Industries Parks Water

77 and Environment 2015) and lacks landscapes subject to extreme change, which are defined as

78 areas with $\leq 5 \%$ of native vegetation (Winfree et al. 2009).

\section{Study design}

80 We established a total of $36 \times 2$-ha plots for bird observations. Of those, 18 plots were

81 located in protected areas (six in each of the three protected areas), 12 in plantations (six each

82 in of the two-plantations) and six in a pasture (Table 1; Fig. 1). The unequal number of sites

83 per land-use category was due to limitations on accessibility. Each site consisted of two

84 subsites, 1-3 km apart, to account for within-site variation. Each subsite consisted of six plots,

85 placed at least $400 \mathrm{~m}$ apart and randomly distributed $80-100 \mathrm{~m}$ from a walking track.

86 Within the 2-ha plots, we identified bird species and recorded their count visually and audibly

87 following the standard protocol recommended by BirdLife (BirdLife 2021), which involves 
88 using a point-count method for 20 minutes. Honeyeaters (family Meliphagidae), were the

89 only birds considered for this study, being the dominant group of nectivorous birds in

90 Australia (Ford and Paton 1977). We also recorded the presence/absence of eucalyptus trees,

91 which we identified to the species level using a field guide by Wiltshire and Potts (2007). The

92 trees were grouped into the sub-genera Symphyomyrtus and Eucalyptus (formerly

93 Monocalyptus) (Nicolle 2015) as they have been shown to influence honeyeater presence

94 (Dunkerley et al. 1990; Woinarski and Cullen 1984).

95 We established a total of 144 plots for bee and beetle observations by selecting, within each

96 of the $36 \times 2$-ha plots, four different ground-level flowering plants. Where possible, four

97 different species of flowering plant were chosen and if none was present no observation was

98 made. Bees and beetles were sampled through visual observations, a commonly used

99 technique to detect bee abundance (Prendergast et al. 2020). Bees were classified as either

100 introduced or native; introduced bees being Apis mellifera (western honeybee) and Bombus

101 terrestris (buff-tailed bumble bee), while native bees included all other bee species. Beetles

102 were identified to family level using the iNaturalist website (https://inaturalist.org/).

103 Flowering plants were identified to species or genus level using the University of Tasmania

104 key to Tasmanian vascular plants (www.utas.edu.au/dicotkey/dicotkey/key.htm).

105 We established a total of 12 transects for butterfly observation. The transects were placed

106 along the walking track between the three 2-ha plots in each of the land-use sites. There were

107 six transects in protected areas (two in each of the three protected-areas land-use sites), four

108 transects in plantations (two in each plantation) and two transects in pasture (Fig. 1).

109 Butterflies were sampled along a 1000-m long and 5-m wide transect (Pollard 1977). An

110 insect net was used to catch butterflies and record count and species. Species were

111 photographed and identified using Common and Waterhouse (1972). 
112 Observations took place between $07.00-11.00 \mathrm{~h}$ and $16.00-19.00 \mathrm{~h}$ for birds, and $10.00-$

$11315.00 \mathrm{~h}$ for insects, under low-wind and non-rainy conditions. Observations of all the

114 investigated pollinator groups were repeated monthly during the Austral spring-summer of

115 2018, from September to December. The advantage of repeated sampling is that it yields

116 higher precision within sites, at the cost of spatial bias, and importantly, it allowed us to

117 account for any temporal changes in flowering vegetation and pollinator presence. Because of

118 temporal changes in flowering vegetation and pollinator presence, we treated the repeated

119 surveys as independent measurements. In total, we performed 144 surveys for birds $(36 \times 2$ -

120 ha plots $\times 4$ months), 576 surveys each for bees and beetles $(36 \times 2$-ha plots $\times 4$ flowering

121 plants $\times 4$ months) and 48 surveys for butterflies (12 transects $\times 4$ months).

122 Table 1. Characteristics of the different land-use sites within each land use

\section{Land use Land-use sites Characteristics based on on-site observations}

$\begin{array}{lll}\text { Protected } & \begin{array}{l}\text { Lime Bay State } \\ \text { areas }\end{array} & \begin{array}{l}\text { Coastal woodland, with pockets of dense tree but overall } \\ \text { open canopy cover and dense ground vegetation. }\end{array} \\ & \begin{array}{l}\text { Tasman National } \\ \text { Park (TNP) (a) }\end{array} & \begin{array}{l}\text { Sclerophyll forest with dense canopy cover and dense } \\ \text { ground vegetation. }\end{array} \\ & \begin{array}{l}\text { Tasman National } \\ \text { Park (TNP) (b) }\end{array} & \begin{array}{l}\text { Sclerophyll forest, with moderate canopy and open ground } \\ \text { vegetation. }\end{array} \\ \text { Plantations } & \text { Plantation (a) } & \text { Contains patches of eucalypt and pine forest plantations and } \\ & & \begin{array}{l}\text { non-plantation eucalypt forest. Fieldwork was done within } \\ \text { the non-plantation eucalypt forest. Sclerophyll forest with } \\ \text { dense canopy and ground cover. }\end{array} \\ & & \text { Contains patches of eucalypt forest and pine plantations and } \\ & & \text { non-plantation eucalypt forest. Fieldwork was done within }\end{array}$


Pasture Pasture

the non-plantation eucalypt forest. Sclerophyll forest with dense canopy and ground cover. We noticed more harvested coups in this site than in plantation (a)

Pasture Pasture

Pasture areas with cattle, with few isolated trees within the pasture.

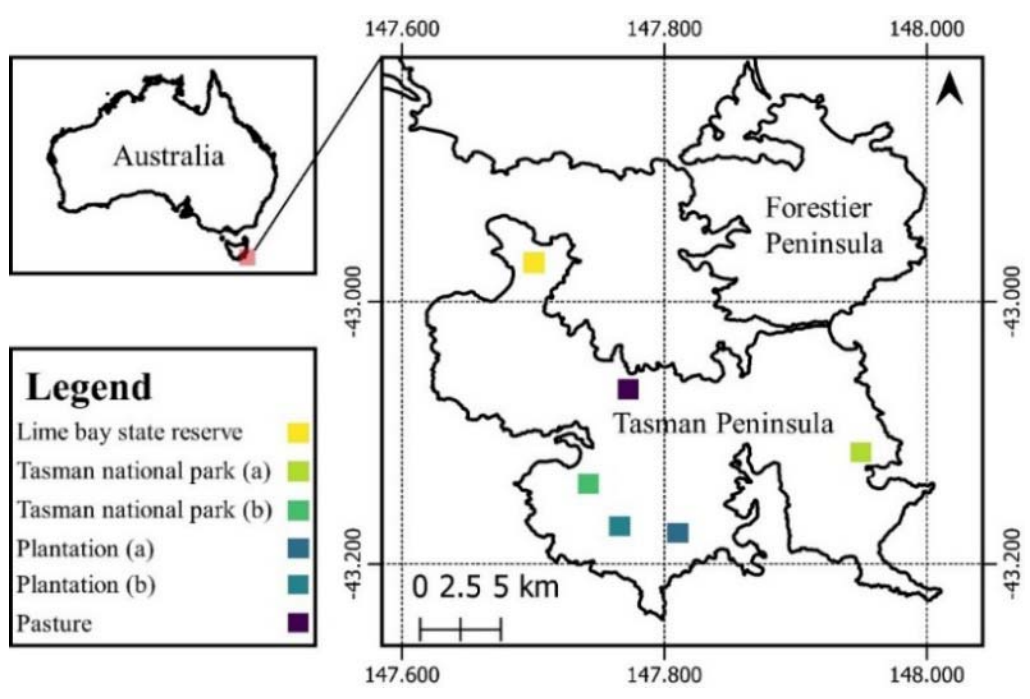

125 Fig. 1 Location of the sampling land-use sites in the Tasman Peninsula, Tasmania, Australia.

126 Land-cover analysis

127 Land cover refers to the natural and artificial structures covering the land (Anderson et al.

128 1976); the land-cover classes considered in this study are 'forest' (areas dominated by trees,

129 including plantations), 'open' (areas with low-lying vegetation, including shrubs and

130 grasses), 'barren' (areas lacking vegetation), and 'water' (quantified as the percentage of total

131 cover at different spatial scales). The allocation of land-cover classes was inferred from

132 Sentinel 2 imagery as it has a high spatial resolution of $10 \times 10 \mathrm{~m}$ (Sentinel Online 2021). 
133 We carried out a pixel-based classification of the imagery following the method outlined by

134 Diengdoh et al. (2020). This method involved, firstly, creating training and validation data for

135 the above-mentioned land-cover classes in QGIS (QGIS Development Team 2021). The

136 training and validation data were used for fitting and tuning the algorithms, and accuracy

137 assessment, respectively. Secondly, machine-learning algorithms (hereafter algorithms) -

138 support vector machine, Random Forests, k-nearest neighbour, and naïve Bayes were trained

139 and used to classify the satellite imagery. Thirdly, the images were classified by the four

140 algorithms using an unweighted ensemble algorithm (Diengdoh et al. 2020).

141 Accuracy was assessed by comparing the output to the validation data, which consisted of

142100 points/pixels per land-cover class, randomly selected from the classified image and

143 visually compared to imagery from Google Earth and field data for accuracy assessment. The

144 output metrics we report include the overall accuracy (OA), the true-skill statistic (TSS) for

145 the classified image, and the sensitivity and specificity of each land-cover class, where: OA is

146 the number of correctly classified pixels divided by the total number of pixels examined

147 (Foody 2002); TSS is equal to sensitivity plus specificity minus 1, where sensitivity is

148 observed presences that are correctly predicted, and specificity is the observed absences that

149 are predicted as such (Allouche et al. 2006). The classification analysis was done in R (R

150 Core Team 2020).

151 The percentage of each land-cover class was calculated within buffers of two different sizes

152 for each pollinator group. We used a buffer of a $2000 \mathrm{~m}$ radius (from the centre of the 2-ha

153 plot and the $1000 \mathrm{~m}$ transect) to represent the land cover within the survey areas as well as its

154 surrounding landscape, and a smaller buffer to represent the land cover within the survey

155 area, which was $100 \mathrm{~m}$ in radius for the birds, bees, and beetles and $500 \mathrm{~m}$ for butterflies. We

156 selected 500m for butterflies because a $100 \mathrm{~m}$ buffer did not encompass the entire $1000 \mathrm{~m}$ 
157 transect. These buffer sizes are similar to those from other studies, e.g., birds (Smith et al.

158 2011), bees (Greenleaf et al. 2007) and butterflies (Bergman et al. 2004).

160 We tested the ability of land use, land cover and plant genera to predict the abundance of

161 each pollinator group. The multi-level categorical predictors 'land use' (3 levels) and 'plant

162 genera' (24 levels), were transformed to dummy variables (i.e., binary presence/absence

163 predictors) to reduce data dimensionality. Keeping land use and plant genera as constant

164 predictors in the model, we compared a model including land cover within the survey area

165 (100 or $500 \mathrm{~m}$ depending on taxa) with a model containing land cover within the surrounding 166 area $(2000 \mathrm{~m})$.

167 Random Forests was used for predictive modelling, implemented using the randomForest $\mathrm{R}$

168 package (Liaw and Wiener 2002). The data was split into 70\%/30\% training/test using a

169 random stratified method so that there was at least one repeated observation in the testing

170 data that was not in the training data. The training data was used for model fitting, assessing

171 partial dependence (PD) plots and individual conditional expectation (ICE) curves and

172 calculating variable importance while the testing data was used for model accuracy, where

173 the out-of-sample $\mathrm{R}^{2}$ and root mean square error (RMSE) of each model was calculated.

174 Models were tuned for different mtry (the hyperparameter in Random Forests) values and the

175 mtry value that resulted in the highest $\mathrm{R}^{2}$ was selected. The PD plots show the marginal effect

176 of a predictor on the predicted outcome (Goldstein et al. 2015). The disadvantage of PD plots

177 is that they show the average effect and heterogeneous effects may be hidden; we used ICE

178 curves to assess those effects (Goldstein et al. 2015). The $p d p$ r package (Greenwell 2017)

179 was used for assessing PD plots and ICE curves. 


\section{$180 \quad$ Results}

\section{Pollinator richness and abundance}

182 We observed a total of 297 honeyeaters belonging to eight different species, of which four are

183 endemic to Tasmania (127 individuals); 511 bees, consisting of 284 native bees (184

184 Exoneura genus, 48 Lasioglossum genus and 52 individuals classified as others) and 227

185 introduced bees (211 honey bees and 16 bumble bees); 423 beetles belonging to nine

186 families; and 84 butterflies belonging to eight species, of which only Pieris rapae is

187 introduced. A list of species observed across the different land-use sites is included in Online

188 Resource 1.

189 The median of the log count of different pollinator groups varied across the six LU sites (Fig.

190 2). Honeyeaters (birds) were more common across the three protected areas than in

191 plantations or pastures (Fig. 2a). However, the median count of the insect pollinators was

192 similar across the different LU sites (Fig. 2b-e).

(a) Honeyeaters

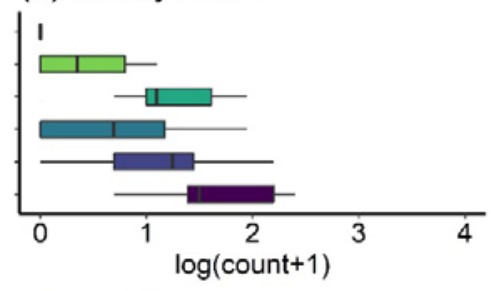

(d) Beetles

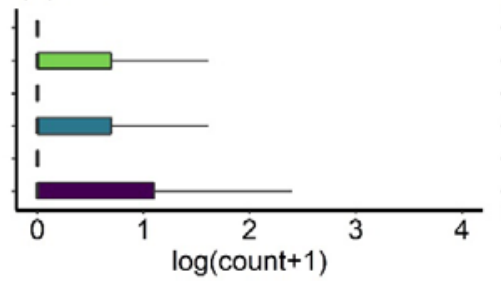

(b) Native bees

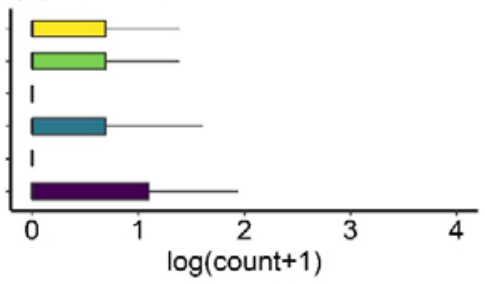

(e) Butterflies (c) Introduced bees

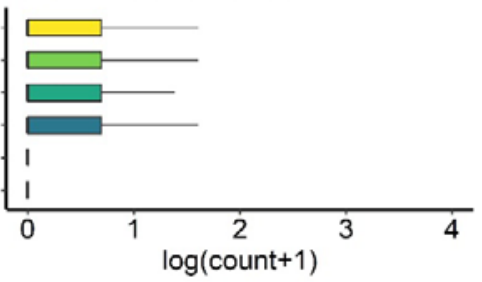

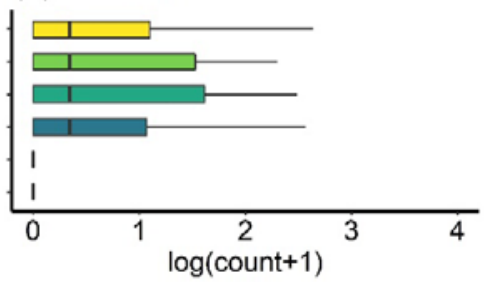

land.use Lime Bay State Reserve Tasman National Park (a) Plantation (a) 
194 Fig. 2 Log of total count (a) honeyeaters, (b-c) bees, (d) beetles and (e) butterflies across

195 protected areas (Tasman National Park a and b, Lime Bay State Reserve), plantations

196 (plantation a and b) and pastures land-use sites.

197 Pollinators showed preference for some plant genera. The median count of honeyeaters was

198 higher in the presence of the eucalypt subgenus Symphyomyrtus compared with the subgenus

199 Eucalyptus (Fig. 3a). Bees and beetles were observed visiting 24 plant genera, of which only

200 three are exotic/naturalised (Arctotheca, Taraxacum and Trifolium, only found in pastures).

201 The median count of native bees was highest in presence of Pultenaea and Melaleuca (Fig.

202 3b), while more introduced bees were found on Anopterus, Lissanthe, Pimelea, Pomaderris,

203 and Trifolium flowers (Fig. 3c). The median count of beetles was highest in association with

204 Leptospermum, Pomaderris and Prostanthera (Fig. 3d).

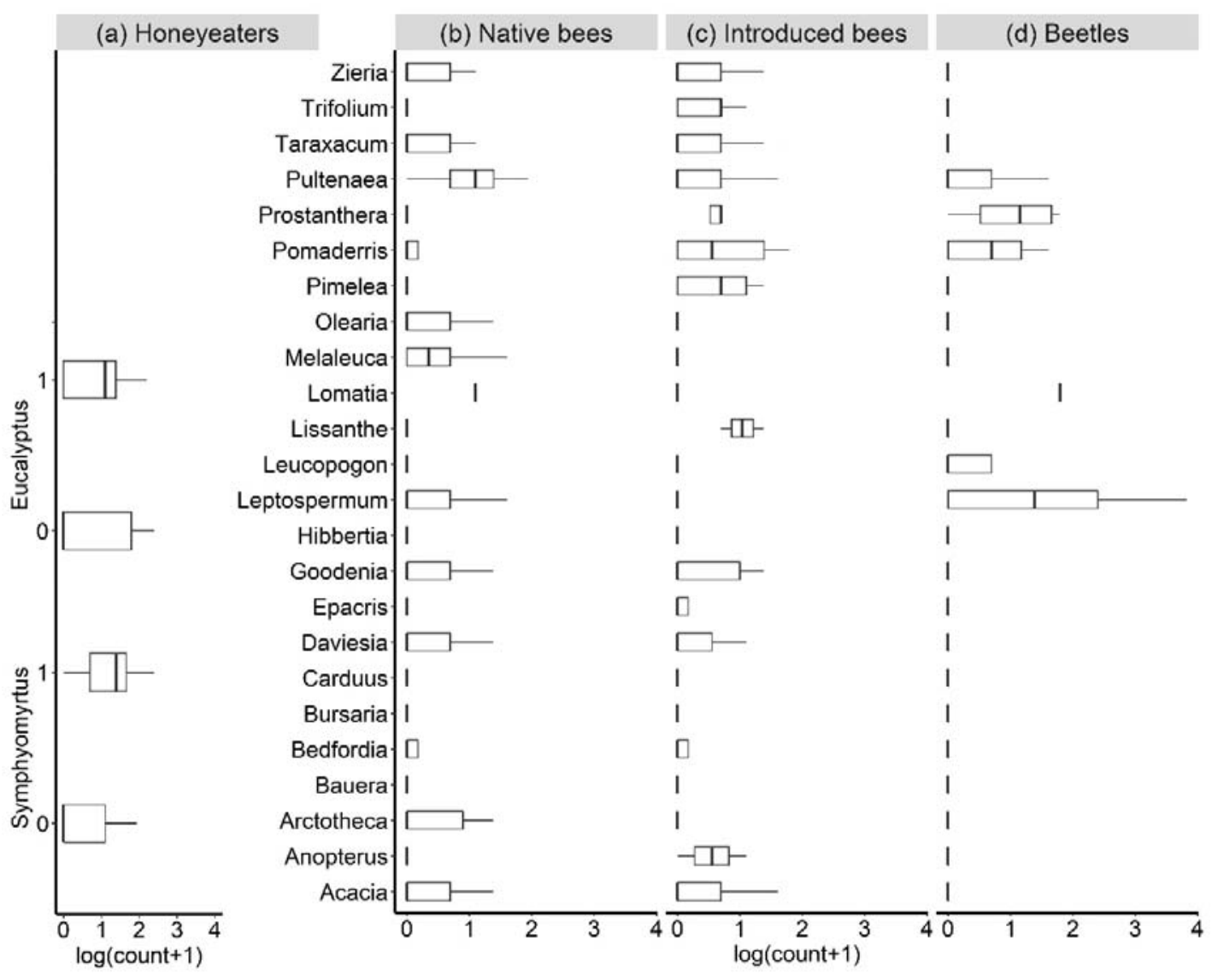


206 Fig. 3 Log of total count (a) honeyeaters, (b) native bees, (c) introduced bees and (d) beetles 207 per genus.

208 Land-cover analysis

209 The classified image (Online Resource 2) had an overall accuracy of $79.5 \%$ with a 95\% CI

$210[75.2,83.4]$ and a true skill statistic score of $77.4 \%$. The confusion matrix of the classification

211 results with sensitivity and specificity of the land-cover classes as well as the percentage of

212 land cover within different buffers are included in the Online Resources (Online Resource 3-

213 6).

214 Predictors of pollinator count

215 The models including land cover within the survey area (100 or $500 \mathrm{~m})$ performed better for

216 introduced bees and beetles and explained $43.9 \%$ and $30.5 \%$ of the variation in pollinator

217 abundance respectively, while the models containing land cover of the broader landscape

218 (2000 m) were better for honeyeaters (49.1\%) and native bees (21.6\%; Table 2). The models

219 for butterfly count were not usefully descriptive $\left(0.01 \mathrm{R}^{2}\right.$; Online Resource 7$)$. The land

220 cover- forest within $2000 \mathrm{~m}$ buffer was the most important predictor for honeyeaters and

221 native bees while open cover within $100 \mathrm{~m}$ buffer and Leptospermum were the most

222 important predictor for introduced bees and beetles, respectively (Online Resource 8). The

223 plant genera Pultenaea and Acacia were the most important predictors for native bees and

224 introduced bees, respectively (Online Resource 8). Land use (i.e., human activities on the

225 land) was not selected as the most important predictor for any of the models; however, it was

226 consistently among the top 10 predictors for the different models (Online Resource 8). 
227 Table 2. The predictive RMSE and $\mathrm{R}^{2}$ (i.e., on out-of-sample test data) of the different

228 pollinator count models using the Random Forests algorithm.

\begin{tabular}{|c|c|c|c|}
\hline Model & Predictors & RMSE & $\mathbf{R}^{2}$ \\
\hline $\begin{array}{c}\text { honeyeater } \\
\text { count }\end{array}$ & $\begin{array}{l}\text { pasture }+ \text { plantation }+ \text { protected } . \text { area }+ \text { Eucalyptus }+ \\
\text { Symphyomyrtus }+ \text { forest } 2000+\text { open } .2000\end{array}$ & 1.632 & 0.491 \\
\hline $\begin{array}{c}\text { native bee } \\
\text { count }\end{array}$ & $\begin{array}{l}\text { pasture + plantation + protected.area + Acacia + Anopterus } \\
+ \text { Arctotheca + Bauera + Bedfordia + Bursaria + Carduus + } \\
\text { Daviesia +Epacris + Goodenia + Hibbertia + } \\
\text { Leptospermum + Leucopogon + Lissanthe + Lomatia + } \\
\text { Melaleuca + Olearia + Pimelea + Pomaderris + } \\
\text { Prostanthera + Pultenaea + Taraxacum + Trifolium + Zieria } \\
+ \text { forest. } 2000+\text { open. } 2000\end{array}$ & 1.810 & 0.216 \\
\hline $\begin{array}{c}\text { introduced } \\
\text { bee } \\
\text { count }\end{array}$ & $\begin{array}{l}\text { pasture + plantation + protected.area + Acacia + Anopterus } \\
+ \text { Arctotheca + Bauera + Bedfordia + Bursaria + Carduus + } \\
\text { Daviesia + Epacris + Goodenia + Hibbertia + } \\
\text { Leptospermum + Leucopogon + Lissanthe + Lomatia + } \\
\text { Melaleuca + Olearia + Pimelea + Pomaderris + } \\
\text { Prostanthera + Pultenaea + Taraxacum + Trifolium + Zieria } \\
+ \text { forest. } 2000+\text { open. } 2000\end{array}$ & 0.870 & 0.439 \\
\hline $\begin{array}{l}\text { beetle } \\
\text { count }\end{array}$ & $\begin{array}{l}\text { pasture + plantation + protected.area + Acacia + Anopterus } \\
+ \text { Arctotheca + Bauera + Bedfordia + Bursaria + Carduus + } \\
\text { Daviesia + Epacris + Goodenia + Hibbertia + } \\
\text { Leptospermum + Leucopogon + Lissanthe + Lomatia + } \\
\text { Melaleuca + Olearia + Pimelea + Pomaderris + } \\
\text { Prostanthera + Pultenaea + Taraxacum + Trifolium + Zieria } \\
+ \text { forest.100 + open. } 100\end{array}$ & 1.976 & 0.305 \\
\hline
\end{tabular}


$230 * *$ Genera: Eucalyptus, Symphyomyrtus, Acacia, Anopterus, Arctotheca, Bauera, Bedfordia,

231 Bursaria, Carduus, Daviesia, Epacris, Goodenia, Hibbertia, Leptospermum, Leucopogon,

232 Lissanthe, Lomatia, Melaleuca, Olearia, Pimelea, Pomaderris, Prostanthera, Pultenaea,

233 Taraxacum, Trifolium, Zieria.

$234 * * *$ Land cover: forest.n and open.n refers to percentage of land cover within buffers of 100

$235 \mathrm{~m}$ or $2000 \mathrm{~m}$ radius.

236 The effect land use had on pollinator count varied between and within pollinator taxa.

237 Protected areas had a positive effect on honeyeater count, but on average had no effect on

238 bees or beetle count (Fig. 4a, d, g, j). However, based on the ICE plots, we found protected

239 areas had both positive and negative effects on bees and beetles (Fig. 4d, g, j). Plantations had

240 a positive effect on beetles but no effect on honeyeater and bees count (Fig. 4b, e, h, k). Yet,

241 based on the ICE plots, we found plantations had both positive and negative effect on

242 honeyeater and bees count (Fig. 4b, e, h). Pasture was the only land use which had a negative

243 effect on honeyeater and beetle count (Fig. 4c, 1). 
(a). Honeyeaters

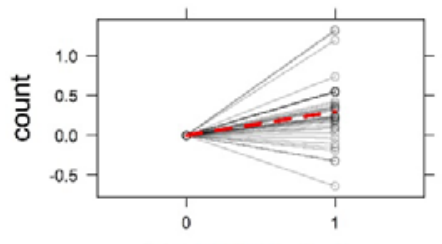

LU_protected.area

(d). Native bees

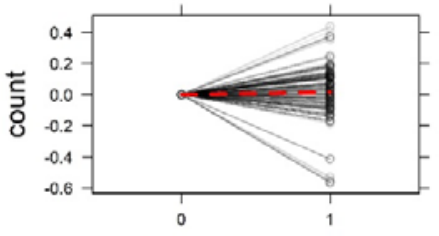

LU_protected.area

(g). Introduced bees

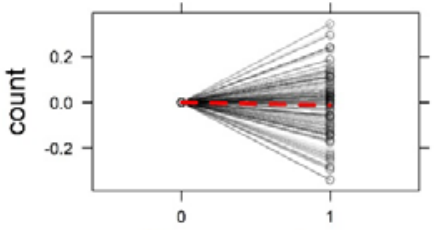

LU_protected.area

(j). Beetles

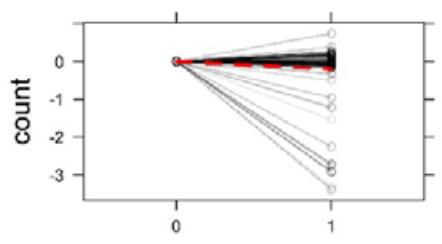

LU_protected.area (b).

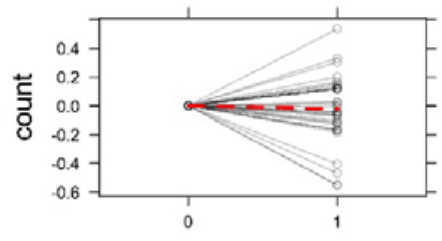

LU_plantation

(e).

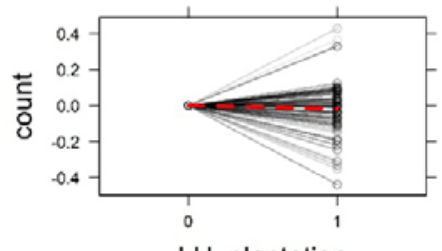

LU_plantation

(h).

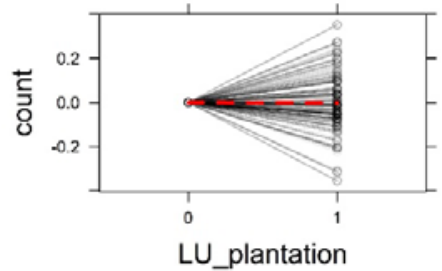

(k).

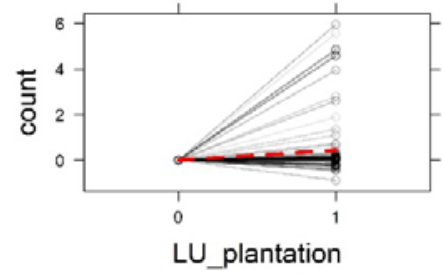

(c).

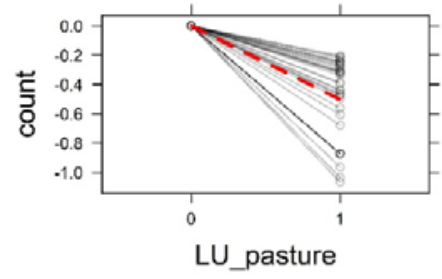

(f).

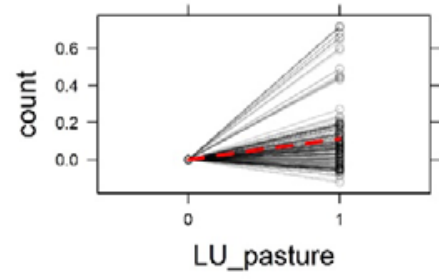

(i).

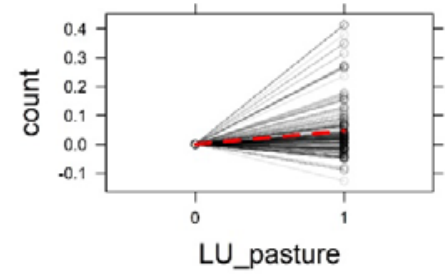

(I).

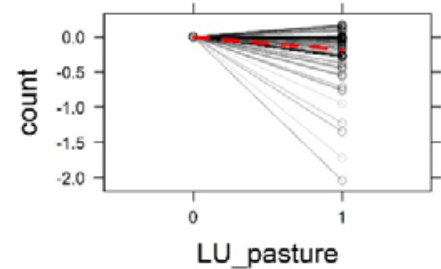

245 Fig. 4 Partial dependence plots (dashed-red lines) and individual conditional expectation

246 (ICE; solid-black lines) curves of the land-use predictors on (a-c) honeyeaters, (d-f) native

247 bees, (g-i) introduced bees, and (j-1) beetle models.

248 Land cover did not have a monotonic or linear relationship with the number of pollinators;

249 rather, it exhibited a stepwise relation with pollinator abundance (Fig. 5). The percentage of

250 forest cover had a positive effect on the number of honeyeaters (Fig. 5b). Conversely, open

251 cover had a negative effect on honeyeaters but positive effect on bees (Fig. 5a, c, e). Overall, 
252 the presence of the different plant genera had a positive effect on the number of different

253 pollinator groups, except for Eucalyptus subgenus Eucalyptus, which had a negative effect on

254 honeyeater count (Fig. 6a). Leucopogon, Pultenaea and Acacia were the three most important

255 variables for native-bee abundance, while Acacia, Melaleuca, and Pomaderris were the three

256 most important variables for introduced bees (Online Resource 8; Fig. 6c-h). Leptospermum

257 Pultenaea and Pomaderris were most important for beetle abundance (Online Resource 8;

258 Fig. 6. i-k). 
(a). Honeyeaters

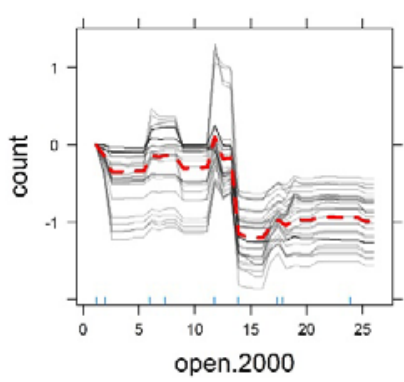

(c). Native bees

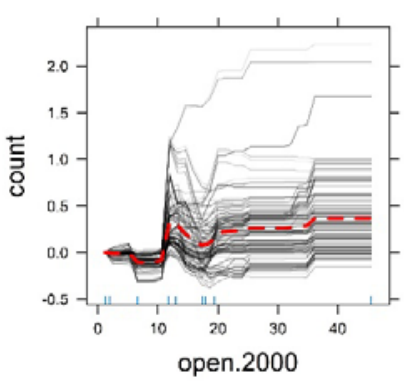

(e). Introduced bees

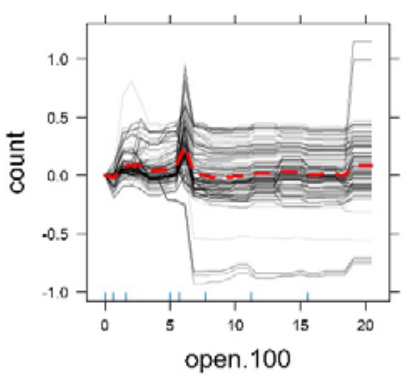

(g). Beetles

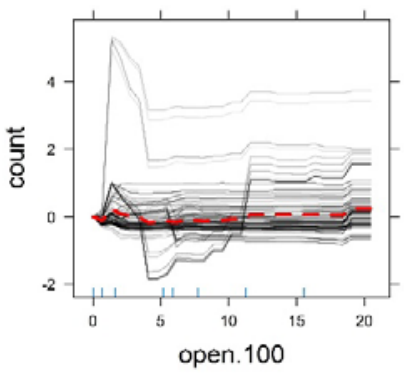

(b).

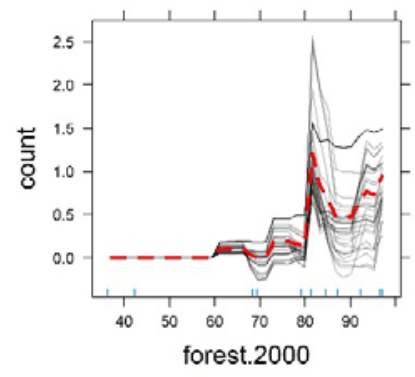

(d).

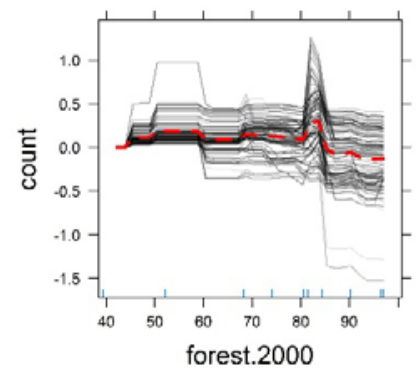

(f).

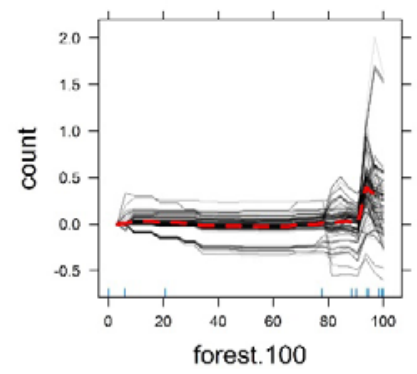

(h).

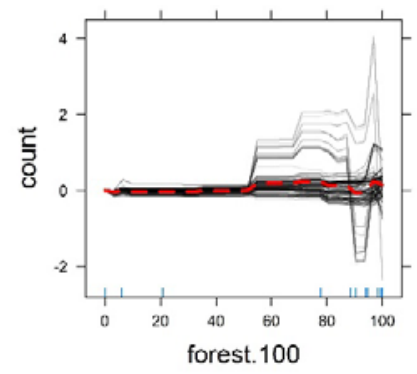

260 Fig. 5 Partial dependence plots (dashed-red lines) and individual conditional expectation

261 (ICE; solid-black lines) curves of the land-cover predictors for (a-b) honeyeaters, (c-d) native

262 bees, (e-f) introduced bees, and (g-h) beetle models. 
(a). Honeyeaters

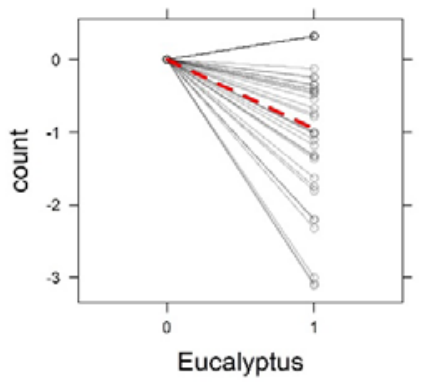

(c). Native bees

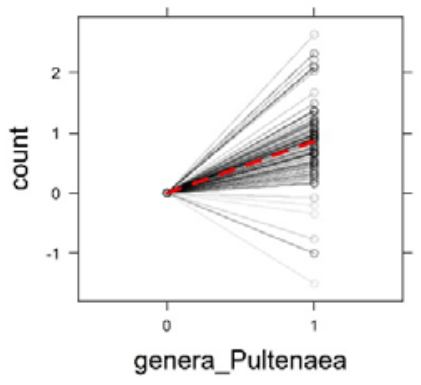

(f). Introduced bees

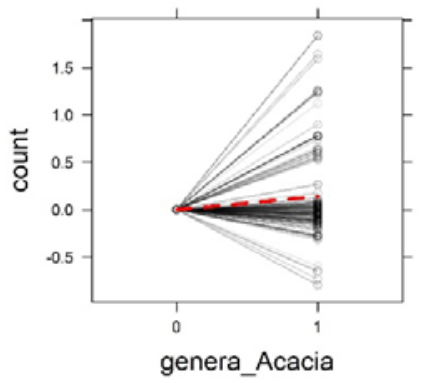

(i). Beetles

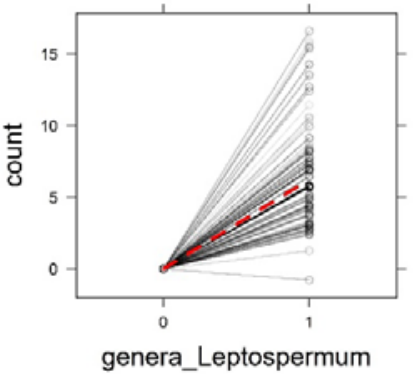

(b).

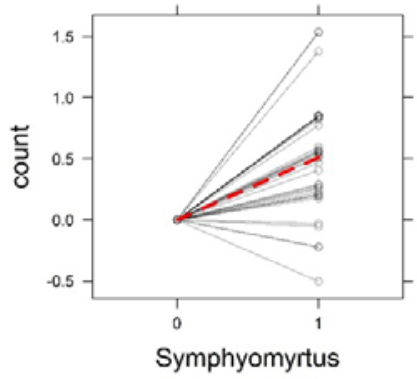

(d).

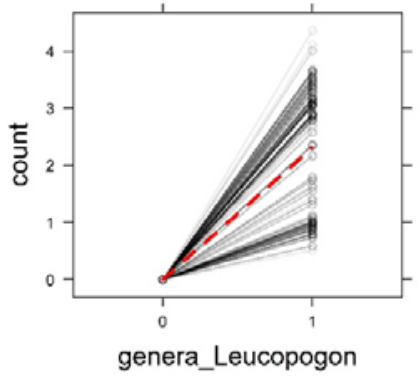

(g).

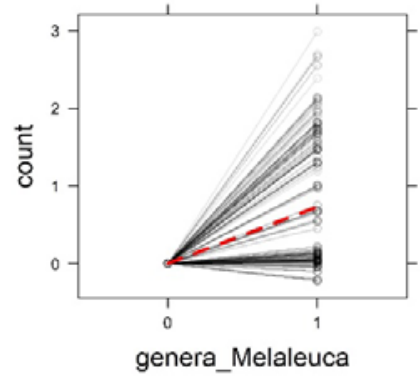

(j).

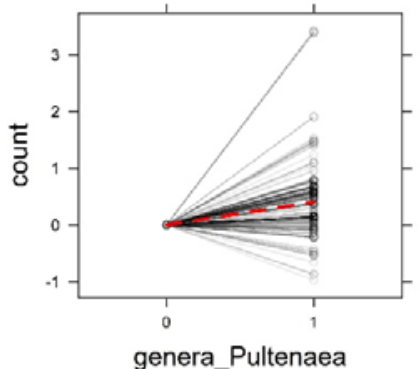

(e).

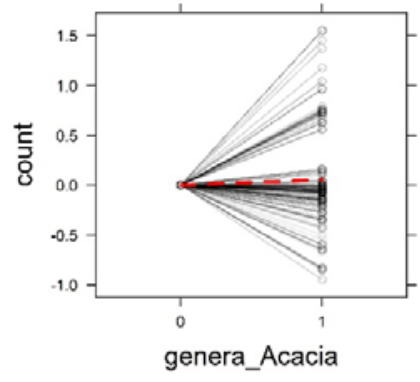

(h).

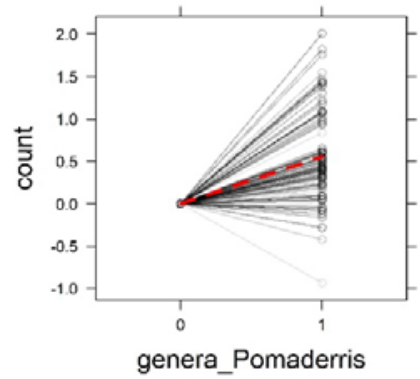

(k).

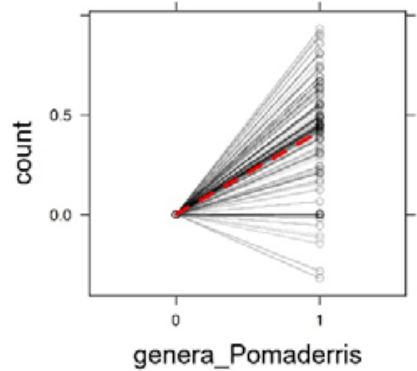

264 Fig. 6 Partial dependence plots (dashed-red lines) and individual conditional expectation

265 (ICE; solid-black lines) curves of the most important genera predictors for (a-b) honeyeaters, 266 (c-e) native bees, (f-h) introduced bees, and (i-k) beetle models. 


\section{Discussion}

268 We assessed the effect of land use, land cover, and plant genera, on the abundance of

269 multiple pollinator groups across a mixed-use, moderately human-modified landscape. We

270 found the percentage of land cover type i.e., forest versus open land cover was the most

271 important predictor for all models as land cover serves as a source of foraging and nesting

272 (Kremen et al. 2007; Öckinger et al. 2012). As expected, given the dependence pollinators on

273 pollen and nectar, the presence of some plant genera had a positive effect on pollinator

274 abundance. The effect of land use on pollinator abundance varied depending on the

275 pollinating taxa, consistent with previous findings (Winfree et al. 2011).

276 The lower importance of land use compared to land cover and plant genera is consistent with

277 existing literature (e.g., De Palma et al. 2016) and suggests that land use might become

278 important only when extremely modified land-use types (e.g., pure agriculture, or urban) are

279 considered (Millard et al. 2021; Winfree et al. 2009; Winfree et al. 2011). The availability of

280 natural habitat and floral resources present in and around different land-use types are more

281 likely to affect pollinators; for example, (1) pollinators can make use of the pollen and nectar

282 provided by plants in road verges or green infrastructure in agricultural and urban landscapes

283 (Daniels et al. 2020; Phillips et al. 2019) and (2) agricultural landscapes with higher amount

284 of high-quality habitat support a higher abundance and richness of pollinators than

285 agricultural landscapes without such habitat (Kavanagh et al. 2007; Kennedy et al. 2013). The

286 positive effect of plantation and pasture land-use types on pollinator taxa could be attributed

287 to the low land-use intensity of the overall study area (Millard et al. 2021) and/or, due to the

288 availability of plantation and non-plantation forest cover and floral resources in plantations

289 and pastures, respectively (Brito et al. 2017; Kavanagh et al. 2007; Kennedy et al. 2013). 
290 The between-taxa variation on the effect of land use was likely due to species-specific

291 requirements and traits, and the within-taxa variation could be due to the coarse taxonomic

292 identification we used. Species traits are known to influence pollinator response to

293 anthropogenic factors (Cariveau and Winfree 2015; De Palma et al. 2015). The visual

294 sampling of bees and beetles allowed us to assess which plants they visited but limited the

295 taxonomic identification of insects, and small samples sizes made the testing of species-

296 specific responses to the predictor variables unfeasible.

297 The predictive capacity of land cover within the survey area (100 $\mathrm{m}$ buffer) versus the land

298 cover within the surrounding area (2000 m buffer) depended on the pollinating taxon, which

299 is consistent with the literature (Bartholomée et al. 2020; Kennedy et al. 2013; Steffan-

300 Dewenter et al. 2002). A possible explanation is that birds, being more mobile, can cover

301 larger distances, and as a result the surrounding land cover was a better predictor than the

302 survey land cover. The difference been introduced bees and native bees could be due to their

303 sizes. Introduced bees consist of honey bees and bumble bees, which are comparatively larger

304 than the native bees. For pollinators such as bees, body size is considered an important factor

305 in their response to land cover at both local and landscape scales (Benjamin et al. 2014). The

306 spatial and temporal distribution of resources is another factor that can influence the effect of

307 land-cover scale on pollinators (Pufal et al. 2017). For instance, the negative impact of open

308 cover on honeyeaters could be due to the lack of resources, as open areas-which tend to lack

309 resources such as food and shelter-are known to negatively impact honeyeaters (Kavanagh

310 et al. 2007), whereas forest cover has been shown to positively influence them (Harrisson et

311 al. 2014). By contrast, resources required by both native and introduced bees could be found

312 in open areas, hence the positive effect on those taxa, consistent with the findings from

313 previous studies (Kaluza et al. 2016). The ICE plots of both open and forest cover showed

314 both had positive and negative impacts on beetles, which might be due to micro-climate, leaf 
315 litter and soil variables, all being known to influence beetles (Fountain-Jones et al. 2015).

316 This suggests that the overall low effect of land cover on beetle counts could be due simply to

317 data paucity. The stepwise relation between land cover and pollinator count could be due to a

318 lack of data covering the entire gradient of percentage of land cover, which would result in

319 the effect 'peaking' or 'dipping' at only certain percentages.

320 The presence of the eucalypt subgenus Eucalyptus was associated with lower honeyeater

321 counts, possibly because of the high abundance of arthropods associated with subgenus

322 Symphyomyrtus compared with Eucalyptus (Dunkerley et al. 1990; Saunders and Burgin

323 2001). This could have led honeyeaters, particularly insectivorous species such as Yellow-

324 throated, Strong-billed, and Black-headed honeyeaters (Thomas 1980), to be more attracted

325 to Symphyomyrtus trees. Pollinator insect abundance was also impacted by the presence of

326 the different plant genera. In particular, the presence of the native genera Acacia, Pultenaea,

327 Pomaderris, Leucopogon, Melaleuca, and Leptospermum was associated with more native

328 bees, introduced bees, and beetles. All these relationships have plausible biological

329 underpinnings. For example, Acacia produces copious pollen (Stone et al. 2003) which is

330 essential for larval provisions for almost all bees (Brosi et al. 2007) while Pultenaea and

331 Pomaderris contain nectar and pollen and are pollinated by bees, beetles and butterflies

332 (Armstrong 1979; De Kok and West 2004; Ogilvie et al. 2009). Leptospermum, in addition to

333 providing nectar and pollen, is also a rich source of fruits and grass-root material which

334 beetles and their larvae feed upon (Andersen and New 1987; Stephens et al. 2005).

335 Overall, we did fond that one size does not fit all — that is, the effects and predictive capacity

336 of land use and land cover in a mixed-use landscape with moderate changes varied depending

337 on the pollinating taxa. Indeed, our results highlight the complexity of pollinator-landscape

338 interactions and that different taxa require different conservation and management policies. 
339 Based on our results for the Tasman Peninsula, we recommend the conservation of a mosaic

340 of forest and open land cover, at both small and large scales. We also recommend the

341 management of native plants (and particularly species belonging to the Acacia, Leucopogon,

342 Leptospermum, Melaleuca, Pomaderris, and Pultenaea genera and the subgenus

343 Symphyomyrtus in Tasmania and mainland Australia where applicable) to attract and sustain

344 a community of pollinators.

345 More generally (beyond this case study), such taxon-specific requirements would be of

346 particular importance in landscapes with extreme change or those dominated by a single land-

347 use type (e.g., urban areas), where creating a mosaic of land-cover types is not an achievable

348 option. These recommendations fall within a known framework of choosing native plants that

349 provide nectar and/or pollen resources for a long temporal span (M'Gonigle et al. 2017; Menz

350 et al. 2011). A major advantage of the approach taken in this study, involving machine

351 learning and predictive modelling, is in its ability to subject conservation-management

352 problems to robust, data-driven assessments, and use these to make informed decisions

353 (Thessen 2016; Willcock et al. 2018). Future studies should consider using both active and

354 passive sampling techniques as well as human observations and mechanised methods such as

355 acoustic recorders for birds (Wimmer et al. 2013) and photographic recording of bees (Steen

356 2017), to obtain a more detailed representation of pollinator communities. Although a past-

357 present comparison would be particularly beneficial for assessing the impacts of land-use and

358 land-cover changes on pollinators, we lacked baseline data on pollinators, making

359 comparative space-for-time assessments a logical substitute. Future studies should explore

360 landscapes and databases that provide opportunities to make past-present comparisons, to

361 better understand the impact of land-use and land-cover changes on pollinator taxa. 


\section{References}

364 Allouche O, Tsoar A, Kadmon R (2006) Assessing the accuracy of species distribution

365 models: prevalence, kappa and the true skill statistic (TSS). Journal of Applied

366 Ecology 43:1223-1232. https://doi.org/10.1111/j.1365-2664.2006.01214.x

367 Andersen AN, New T (1987) Insect inhabitants of fruits of Leptospermum, Eucalyptus and

368 Casuarina in southeastern Australia. Australian Journal of Zoology 35:327-336.

$369 \quad$ https://doi.org/10.1071/ZO9870327

370 Anderson JR, Hardy EE, Roach JT, Witmer RE (1976) A land use and land cover

371 classification system for use with remote sensor data. Professional Paper 964. US

372 Government Printing Office, Washington DC https://doi.org/10.3133/pp964

373 Armstrong J (1979) Biotic pollination mechanisms in the Australian flora-a review. New

$374 \quad$ Zealand Journal of Botany 17:467-508.

$375 \quad$ https://doi.org/10.1080/0028825X.1979.10432565

376 Australian Bureau of Statistics (2021) Region summary: Tasman (M).

377 https://dbr.abs.gov.au/region.html?lyr=lga\&rgn=65210. Accessed 22/04/2021

378 Bartholomée O, Aullo A, Becquet J, Vannier C, Lavorel S (2020) Pollinator presence in

379 orchards depends on landscape-scale habitats more than in-field flower resources.

$380 \quad$ Agriculture, Ecosystems \& Environment 293:106806.

$381 \quad$ https://doi.org/10.1016/j.agee.2019.106806

382 Baude M, Kunin WE, Boatman ND, Conyers S, Davies N, Gillespie MA, Morton RD, Smart

383 SM, Memmott J (2016) Historical nectar assessment reveals the fall and rise of floral

384 resources in Britain. Nature 530:85. https://doi.org/10.1038/nature16532 
385 Benjamin FE, Reilly JR, Winfree R (2014) Pollinator body size mediates the scale at which

386 land use drives crop pollination services. Journal of Applied Ecology 51:440-449.

387 https://doi.org/10.1111/1365-2664.12198

388 Bergman KO, Askling J, Ekberg O, Ignell H, Wahlman H, Milberg P (2004) Landscape

389 effects on butterfly assemblages in an agricultural region. Ecography 27:619-628.

$390 \quad$ https://doi.org/10.1111/j.0906-7590.2004.03906.x

391 BirdLife (2021) Survey Techniques. https://birdata.birdlife.org.au/survey-techniques.

$392 \quad$ Accessed 22/04/2021

393 Brito TF, Phifer CC, Knowlton JL, Fiser CM, Becker NM, Barros FC, Contrera FA, Maués

394 MM, Juen L, Montag LF (2017) Forest reserves and riparian corridors help maintain

395 orchid bee (Hymenoptera: Euglossini) communities in oil palm plantations in Brazil.

396 Apidologie 48:575-587. https://doi.org/10.1007/s13592-017-0500-z

397 Brosi BJ, Daily GC, Ehrlich PR (2007) Bee community shifts with landscape context in a

398 tropical countryside. Ecological Applications 17:418-430. https://doi.org/10.1890/06-

$399 \underline{0029}$

400 Brown M, Duncan F (1986) The vegetation of Tasman Peninsula. Papers and Proceedings of

401 the Royal Society of Tasmania:33-50.

402 Campbell AJ, Carvalheiro LG, Gastauer M, Almeida-Neto M, Giannini TC (2019) Pollinator

403 restoration in Brazilian ecosystems relies on a small but phylogenetically-diverse set

404 of plant families. Scientific Reports 9:1-10. https://doi.org/10.1038/s41598-019-

$405 \underline{53829-4}$

406 Cariveau DP, Winfree R (2015) Causes of variation in wild bee responses to anthropogenic

407 drivers. Current Opinion in Insect Science 10:104-109.

$408 \quad$ https://doi.org/10.1016/j.cois.2015.05.004 
409 Common IFB, Waterhouse DF (1972) Butterflies of Australia. Angus and Robertson, Sydney

410 Daniels B, Jedamski J, Ottermanns R, Ross-Nickoll M (2020) A “plan bee” for cities:

411 Pollinator diversity and plant-pollinator interactions in urban green spaces. PLoS One

412 15:e0235492. https://doi.org/10.1371/journal.pone.0235492

413 De Kok R, West J (2004) A revision of the genus Pultenaea (Fabaceae). 3. The eastern

414 species with recurved leaves. Australian Systematic Botany 17:273-326.

$415 \quad$ https://doi.org/10.1071/SB02028

416 De Palma A, Abrahamczyk S, Aizen MA, Albrecht M, Basset Y, Bates A, Blake RJ, Boutin

417 C, Bugter R, Connop S (2016) Predicting bee community responses to land-use

418 changes: Effects of geographic and taxonomic biases. Scientific Reports 6:31153.

419 https://doi.org/10.1038/srep31153

420 De Palma A, Kuhlmann M, Roberts SP, Potts SG, Börger L, Hudson LN, Lysenko I,

421 Newbold T, Purvis A (2015) Ecological traits affect the sensitivity of bees to

422 land $\square$ use pressures in European agricultural landscapes. Journal of Applied Ecology

$423 \quad 52: 1567-1577$. https://doi.org/10.1111/1365-2664.12524

424 Department of Primary Industries Parks Water and Environment (2015) Tasmanian Land Use 4252015.

426 Diengdoh VL, Ondei S, Hunt M, Brook BW (2020) A validated ensemble method for

427 multinomial land-cover classification. Ecological Informatics 56:101065.

$428 \quad$ https://doi.org/10.1016/j.ecoinf.2020.101065

429 Dunkerley GM, Ford H, Danthanarayana W (1990) The fuscous honeyeater: food resources

430 and the bird community. Dissertation, University of New England

431 Foody GM (2002) Status of land cover classification accuracy assessment. Remote Sensing

432 of Environment 80:185-201. https://doi.org/10.1016/S0034-4257(01)00295-4 
433 Ford HA, Paton DC (1977) The comparative ecology of ten species of honeyeaters in South

434 Australia. Australian Journal of Ecology 2:399-407. https://doi.org/10.1111/j.1442-

$435 \quad$ 9993.1977.tb01155.x

436 Fountain-Jones NM, Jordan GJ, Baker TP, Balmer JM, Wardlaw T, Baker SC (2015) Living

437 near the edge: being close to mature forest increases the rate of succession in beetle

$438 \quad$ communities. Ecological Applications 25:800-811. https://doi.org/10.1890/14-0334.1

439 Goldstein A, Kapelner A, Bleich J, Pitkin E (2015) Peeking inside the black box: Visualizing

440 statistical learning with plots of individual conditional expectation. Journal of

$441 \quad$ Computational and Graphical Statistics 24:44-65.

$442 \quad$ https://doi.org/10.1080/10618600.2014.907095

443 Greenleaf SS, Williams NM, Winfree R, Kremen C (2007) Bee foraging ranges and their

444 relationship to body size. Oecologia 153:589-596. https://doi.org/10.1007/s00442-

$445 \underline{007-0752-9}$

446 Greenwell BM (2017) pdp: An R Package for Constructing Partial Dependence Plots. The R

447 Journal 9:421-436. https://journal.r-project.org/archive/2017/RJ-2017-016/index.html

448 Harrisson KA, Pavlova A, Amos JN, Radford JQ, Sunnucks P (2014) Does reduced mobility

449 through fragmented landscapes explain patch extinction patterns for three

450 honeyeaters? Journal of Animal Ecology 83:616-627. https://doi.org/10.1111/1365-

$451 \quad \underline{2656.12172}$

452 Kaluza BF, Wallace H, Heard TA, Klein AM, Leonhardt SD (2016) Urban gardens promote

453 bee foraging over natural habitats and plantations. Ecology and Evolution 6:1304-

454 1316. https://doi.org/10.1002/ece3.1941

455 Kavanagh RP, Stanton MA, Herring MW (2007) Eucalypt plantings on farms benefit

456 woodland birds in south $\square$ eastern Australia. Austral Ecology 32:635-650. 
457 Kennedy CM, Lonsdorf E, Neel MC, Williams NM, Ricketts TH, Winfree R, Bommarco R, 458 Brittain C, Burley AL, Cariveau D (2013) A global quantitative synthesis of local and $459 \quad$ landscape effects on wild bee pollinators in agroecosystems. Ecology Letters 16:584460 599. https://doi.org/10.1111/ele.12082

461 Klein AM, Vaissiere BE, Cane JH, Steffan-Dewenter I, Cunningham SA, Kremen C, 462 Tscharntke T (2007) Importance of pollinators in changing landscapes for world crops. Proceedings of the Royal Society B: Biological Sciences 274:303-313.

Kral-O’Brien KC, O’Brien PL, Hovick TJ, Harmon JP (2021) Meta-analysis: Higher Plant Richness Supports Higher Pollinator Richness Across Many Land Use Types. Annals of the Entomological Society of America https://doi.org/10.1093/aesa/saaa061 ecosystem services produced by mobile organisms: a conceptual framework for the effects of land $\square$ use change. Ecology Letters 10:299-314. When Restoring Habitat for Pollinators. Conservation Letters 10:105-111. https://doi.org/10.1111/conl.12261

478 Maes D, Van Dyck H (2001) Butterfly diversity loss in Flanders (north Belgium): Europe's 479 worst case scenario? Biological Conservation 99:263-276.

$480 \quad$ https://doi.org/10.1016/S0006-3207(00)00182-8 
481 Menz MH, Phillips RD, Winfree R, Kremen C, Aizen MA, Johnson SD, Dixon KW (2011)

482 Reconnecting plants and pollinators: challenges in the restoration of pollination

483 mutualisms. Trends in Plant Science 16:4-12.

484

https://doi.org/10.1016/j.tplants.2010.09.006

485

486

487

488

489

490

491

492

493

494

495

496

497

498

499

500

501

502

503

Millard J, Outhwaite CL, Kinnersley R, Freeman R, Gregory RD, Adedoja O, Gavini S, Kioko E, Kuhlmann M, Ollerton J (2021) Global effects of land-use intensity on local pollinator biodiversity. Nature Communications 12:1-11.

https://doi.org/10.1038/s41467-021-23228-3

Montero-Castaño A, Vilà M (2012) Impact of landscape alteration and invasions on pollinators: a meta-analysis. Journal of Ecology 100:884-893. https://doi.org/10.1111/j.1365-2745.2012.01968.x

Nicolle D (2015) Classification of the eucalypts (Angophora, Corymbia and Eucalyptus) Version 4. https://dn.com.au/Classification-Of-The-Eucalypts.pdf.

Nicolson SW, Wright GA (2017) Plant-pollinator interactions and threats to pollination: perspectives from the flower to the landscape. Functional Ecology 31:22-25. https://doi.org/10.1111/1365-2435.12810

Öckinger E, Bergman K-O, Franzén M, Kadlec T, Krauss J, Kuussaari M, Pöyry J, Smith HG, Steffan-Dewenter I, Bommarco R (2012) The landscape matrix modifies the effect of habitat fragmentation in grassland butterflies. Landscape Ecology 27:121131. https://doi.org/10.1007/s10980-011-9686-z

Ogilvie JE, Zalucki JM, Boulter SL (2009) Pollination biology of the sclerophyllous shrub Pultenaea villosa Willd.(Fabaceae) in southeast Queensland, Australia. Plant Species Biology 24:11-19. https://doi.org/10.1111/j.1442-1984.2009.00235.x 
504 Ollerton J, Erenler H, Edwards M, Crockett R (2014) Pollinator declines. Extinctions of

505 aculeate pollinators in Britain and the role of large-scale agricultural changes. Science

506 346:1360-1362. https://doi.org/10.1126/science.1257259

507 Ollerton J, Winfree R, Tarrant S (2011) How many flowering plants are pollinated by

508 animals? Oikos 120:321-326. https://doi.org/10.1111/j.1600-0706.2010.18644.X

509 Paton DC (2000) Disruption of bird $\square$ plant pollination systems in southern Australia.

510 Conservation Biology 14:1232-1234. https://doi.org/10.1046/j.1523-

$511 \quad \underline{1739.2000 .00015 . x}$

512 Phillips BB, Gaston KJ, Bullock JM, Osborne JL (2019) Road verges support pollinators in

513 agricultural landscapes, but are diminished by heavy traffic and summer cutting.

$514 \quad$ Journal of Applied Ecology 56:2316-2327. https://doi.org/10.1111/1365-2664.13470

515 Pollard E (1977) A method for assessing changes in the abundance of butterflies. Biological

516 Conservation 12:115-134. https://doi.org/10.1016/0006-3207(77)90065-9

517 Potts SG, Biesmeijer JC, Kremen C, Neumann P, Schweiger O, Kunin WE (2010) Global

518 pollinator declines: trends, impacts and drivers. Trends in Ecology \& Evolution

$519 \quad$ 25:345-353. https://doi.org/10.1016/j.tree.2010.01.007

520 Prendergast KS, Menz MHM, Dixon KW, Bateman PW (2020) The relative performance of

521 sampling methods for native bees: an empirical test and review of the literature.

$522 \quad$ Ecosphere 11:e03076. https://doi.org/10.1002/ecs2.3076

523 Pufal G, Steffan-Dewenter I, Klein A-M (2017) Crop pollination services at the landscape

524 scale. Current Opinion in Insect Science 21:91-97.

$525 \quad$ https://doi.org/10.1016/j.cois.2017.05.021

526 QGIS Development Team (2021) QGIS Geographic Information System. QGIS Association.

527 version 3.12.1. https://www.qgis.org 
528 R Core Team (2020) R: A language and environment for statistical computing. R Foundation

529 for Statistical Computing, Vienna, Austria. version 4.0.5. https://www.R-project.org/

530 Regan EC, Santini L, Ingwall-King L, Hoffmann M, Rondinini C, Symes A, Taylor J,

531 Butchart SHM (2015) Global Trends in the Status of Bird and Mammal Pollinators.

$532 \quad$ Conservation Letters 8:397-403. https://doi.org/10.1111/conl.12162

533 Sabatino M, Rovere A, Meli P (2021) Restoring pollination is not only about pollinators:

534 Combining ecological and practical information to identify priority plant species for

535 restoration of the Pampa grasslands of Argentina. Journal for Nature Conservation

$536 \quad$ 61:126002. https://doi.org/10.1016/j.jnc.2021.126002

537 Saunders AS, Burgin S (2001) Selective foliage foraging by Red Wattlebirds, Anthochaera

538 carunculata, and Noisy Friarbirds, Philemon corniculatus. Emu 101:163-166.

539 https://doi.org/10.1071/MU00007

540 Senapathi D, Goddard MA, Kunin WE, Baldock KCR (2016) Landscape impacts on

541 pollinator communities in temperate systems: evidence and knowledge gaps.

$542 \quad$ Functional Ecology 31:26-37. https://doi.org/10.1111/1365-2435.12809

543 Sentinel Online (2021) Sentinel-2 Spatial Resolutions

$544 \quad$ https://sentinel.esa.int/web/sentinel/user-guides/sentinel-2-msi/resolutions/spatial.

$545 \quad$ Accessed 22/04/2021

546 Smith AC, Fahrig L, Francis CM (2011) Landscape size affects the relative importance of

547 habitat amount, habitat fragmentation, and matrix quality on forest birds. Ecography

$548 \quad$ 34:103-113. https://doi.org/10.1111/j.1600-0587.2010.06201.x

549 Steen R (2017) Diel activity, frequency and visit duration of pollinators in focal plants: in situ 550 automatic camera monitoring and data processing. Methods in Ecology and Evolution

551 8:203-213. https://doi.org/10.1111/2041-210X.12654 
552 Steffan-Dewenter I, Münzenberg U, Bürger C, Thies C, Tscharntke T (2002)

553 Scale $\square$ dependent effects of landscape context on three pollinator guilds. Ecology

555 Stephens J, Molan PC, Clarkson BD (2005) A review of Leptospermum scoparium

(Myrtaceae) in New Zealand. New Zealand Journal of Botany 43:431-449. https://doi.org/10.1080/0028825X.2005.9512966

558 Stone GN, Raine NE, Prescott M, Willmer PG (2003) Pollination ecology of acacias

559 (Fabaceae, Mimosoideae). Australian Systematic Botany 16:103-118.

$560 \quad$ https://doi.org/10.1071/SB02024

561 Thessen A (2016) Adoption of machine learning techniques in ecology and earth science.

$562 \quad$ One Ecosystem 1:e8621. https://doi.org/10.3897/oneeco.1.e8621

563 Thomas D (1980) Foraging of honeyeaters in an area of Tasmanian sclerophyll forest. Emu

564 80:55-58. https://doi.org/10.1071/MU9800055

565 Vanbergen AJ, Insect Pollinators Initiative (2013) Threats to an ecosystem service: pressures

566 on pollinators. Frontiers in Ecology and the Environment 11:251-259.

$567 \quad$ https://doi.org/10.1890/120126

568 Willcock S, Martínez-López J, Hooftman DA, Bagstad KJ, Balbi S, Marzo A, Prato C,

569 Sciandrello S, Signorello G, Voigt B (2018) Machine learning for ecosystem services.

570 Ecosystem Services 33:165-174. https://doi.org/10.1016/j.ecoser.2018.04.004

571 Wiltshire R, Potts B (2007) EucaFlip-Life-size guide to the eucalypts of Tasmania.

$572 \quad$ University of Tasmania,

573 Wimmer J, Towsey M, Roe P, Williamson I (2013) Sampling environmental acoustic

574 recordings to determine bird species richness. Ecological Applications 23:1419-1428.

$575 \quad$ https://doi.org/10.1890/12-2088.1 
576 Winfree R, Aguilar R, Vazquez DP, LeBuhn G, Aizen MA (2009) A meta-analysis of bees'

577 responses to anthropogenic disturbance. Ecology 90:2068-2076.

$578 \quad$ https://doi.org/10.1890/08-1245.1

579 Winfree R, Bartomeus I, Cariveau DP (2011) Native Pollinators in Anthropogenic Habitats.

$580 \quad$ Annual Review of Ecology, Evolution, and Systematics 42:1-22.

$581 \quad$ https://doi.org/10.1146/annurev-ecolsys-102710-145042

582 Woinarski J, Cullen J (1984) Distribution of invertebrates on foliage in forests of

$583 \quad$ south $\square$ eastern Australia. Australian Journal of Ecology 9:207-232.

$584 \quad$ https://doi.org/10.1111/j.1442-9993.1984.tb01359.x

585 